\title{
AN ANALYSIS OF WOMEN'S STATUS IN THE MUSLIM SYSTEM AS OPPOSED TO THE EUROPEAN
}

\section{O. Ghiţă}

\author{
Oana Ghiţă \\ Law Faculty \\ University of Craiova, Craiova, Romania \\ Corespondence: Oana Ghiţă, University of Craiova, Law Faculty, \\ 107D Calea Bucureşti, Craiova, Romania \\ E-mail: ghita.oana@gmail.com
}

Abstract:

Article 14 of the ECHR Convention guarantees women the same rights as men. This is just one example. Gender equality is recognized in the Romanian legal system from the constitutional level - Article 16. The Coran guarantees equality between women and men. How is the woman subject to the protection of her husband in each of these law systems? We propose to analyze this in this article.

Keywords: Islam, Muslims, women's rights, marriage, ECHR.

\section{Introduction}

Both from a structural and especially substantive point of view, the legislative system in Europe is very different from the Muslim system, even if over time there have been attempts at dialogue in the sense of near convergence of the two great systems.

In this study, we propose a brief analysis of what married life means for Muslim women, compared with the rights and obligations of married woman under legal texts at European level in general, and in particular her status as regulated by the Romanian legislation. Interest in this subject lies in the controversy that the "Western world" and the "Muslim world" grant women rights that place her in an uncertain area - the woman is protected by or subject to environment in which "functions"?

\section{Common Legal Principles Applied Differently}

In order to understand and analyze how the state of Muslim women is regulated, we consider it necessary to look at a few aspects of the Islamic legal system.

For Islam, the Qur'an is the central reality around which all other beings and things revolve. The Qur'an contains the message that helps to maintain the pact between man, the servant of God, and God ${ }^{1}$. It is not the written text of the prophet Mohammed but the word of Allah to the prophet who is just a messenger. From the legal point of view, the Qur'an along with the Shari'ah is the basis of Islamic law.

\subsection{The Principle of Equality of Rights}

Equality of the sexes is presented and interpreted from the Qur'an: "Do you despise the work of any of you, male or female, for one from another on moving" $(3: 195)^{2}$

We will see many such texts in the Qur'an, but none that actually confers gender equality or any non-discrimination principle as owe are accustomed to in the European Convention on Human Rights or domestic provisions of our state.

Moreover, we shall see this equality treated in a manner different from the European way, because man and woman are equal to where differences occur natural, physical and

\footnotetext{
${ }^{1}$ Ş. Reşceanu, Islamul între istorie şi modernitate, Ed. Universitaria Craiova, 2007, p. 27.

${ }^{2}$ Y. Al-Qaradawy, Statutul femeilor in Islam, Ed. Taiba, Bucureşti, 2008, p. 23.
} 


\section{EUROPEAN}

moral. For example, a woman is considered more attached to her emotional life and much more easily influenced by her emotions than a man who is considered to be dominated by rational thought. In this context, women cannot hold an administrative, political or juridical position, given that in performing the required function her emotions would take precedence over rationality. ${ }^{3}$

\subsection{The Principle of Human Dignity}

It should be noted that differences in history, culture and mentality between Westerners and Muslims have led the latter to consider that they cannot be forced to abide by the UN Declaration, but must make their own statement on human rights. ${ }^{4}$ Throughout history, we see many attempts at such statements. Thus, the Declaration of Human Rights, the second part in which were provided the conclusions and recommendations of the 1980 Kuwait symposium $^{5}$ states that Islam gave women a worthy and honorable status long before the advent and enshrinement of modern human rights. ${ }^{6}$

The status of dignity and honor that Muslims give their women much disputed along with the much disputed equality between men and women are supported, in a slightly different manner, however, by the Qur'an. Thus, it establishes the man's authority over the woman by virtue of the preference that God has bestowed to it. "Rebuked those you think unfaithful; close them in separate rooms and beat them"(Qur'an 4:34)

Even though this is the text of the Qur'an, it seems that its true meaning can only be discerned by a Muslim, because "this verse in no way endorses domestic violence (...) The main method of interpreting the Qur'an applied by scientists is intertextual reading of the text." In this manner, "it becomes clear that the Qur'an prescribes both partners to be treated with respect, justice and benevolence" However, it is explained to us how is to be interpreted and what this text represents to the real life of women in Islam. Despite all this, it has been admitted that "religion is never a cause of domestic violence. While Muslim men try to justify the abuse through this verse, the truth is that the reason for this abuse is not and can never be religion."

\subsection{Principles of Social Coexistence in Matters of Family Relationships}

Distinguishing it from the Qur'an, Shari'ah represents the sacred law of Islam that includes jurisprudence. Shari'ah has known over time and depending on every Muslim country, changes and improvements made by the prophets in line with social particularities, political and economic aspects of the time. Religious and secular law are separated from one another.

We could say that in Shari'ah can be found the rules of conduct for any Muslim, rules that if broken attract the penalties from the state authorities, and especially from the community. "Shari'ah is for Islam the way that enables to integrate persons in society. (...) The Divine Law is a network of command and attitudes that govern all human life and which, taken as a whole, allow people to integrate into society, as the dominant principle of Islam." 9 Precisely because it is for all Muslims, Shari'ah is not made up of teaching general, but specific rules applicable in daily life. Thus it includes human actions into five categories: obligatory, recommended and meritorious, prohibited, reprehensible and indifferent. ${ }^{10}$

\footnotetext{
${ }^{3}$ Idem, p. 40.

${ }^{4}$ Ş. Reşceanu, op. cit., p. 162.

5 The Kuweit Colloquium was organised by the International Commission of Jurists, University of Kuweit and the Union of Arabic Lawyers, Kuweit, 9-14 December 1980.

${ }^{6}$ S. A. Aldeeb Abu-Sahlieh, Projets de constitutions et droits de l'homme islamique, Studia Arabica VIII, Ed. De Paris, 2008, p. 152.

${ }^{7}$ Muslim Women Association, Femeia în Islam, Ed. Femeia musulmană, Bucureşti, 2013, p. 115.

${ }^{8}$ Idem, p. 129.

${ }^{9}$ S. H. Nasr, Islam. Perspectives et realites, Ed. Buchet/Chastel, 1991, p. 115.

${ }^{10}$ Ş. Reşceanu, op. cit., p. 39.
} 


\section{O. Ghiţă}

In matters of family relationships, we could include into each of these categories the following facts:

- Compulsory: marriage, divorce when the woman does not listen to the man, female circumcision;

- Meritorious and recommended: the martyrdom of women dying in childbirth;

- Prohibited: the interdiction of having two sisters as wives; it is forbidden for the wife of the younger brother to marry his elder brother (the reverse situation is allowed); prohibition to marry one's sister, niece, daughter or aunt; adultery (represented by looking or touching another woman);

- Reprehensible: the rules are not of great importance, being more rules on hygiene and nutrition;

- Indifferent: they do not cause "legal effects" in the sense that they not attract any penalties, nor rewards.

It is not difficult to recognize in these Islamic rules, even classified as Shari'ah some of the impediments to marriage regulated in the Romanian legal system: an example might be the prohibition of marriage between relatives enshrined in Article 274 of the Romanian Civil Code.

On the status of the woman to her husband, Shari'ah comprises of three categories of rights and obligations: reciprocal rights and obligations, rights and obligations that man has towards his wife, rights and obligations which the woman has towards her man - the woman can never have more rights than obligations.

\subsection{The Monogamous/Polygamous Marriage}

Unlike European countries, or rather, most Christian countries, that have regulated monogamous marriage - since polygamy is most often penalized both by civil (nullity of marriage later concluded), but also criminal law - it is very well known that the majority of Muslim countries have established rules that support polygamy.

At a European level, the European Convention on Human Rights affirms marriage between a man and a woman and subjects the celebration of the marriage to the rules regulated at a national level. Thus, the Romanian Civil Code regulates in article 273 the prohibition of a person who is married to enter into a new marriage. In terms of civil law, the penalty for violating this legal text is then the complete nullity of marriage (according to article 293 of the Romanian Civil Code) ${ }^{11}$. In terms of criminal law, according to art. 376 of the Romanian Penal Code, the imposed penalty for the conclusion of a new marriage by a married person is imprisonment from 3 months to 2 years or a fine.

"Several societies wished the occidentalization of the Muslim women, but they didn't succeed in each time because they were educated according to the Islamic moral and didn't change their opinion; one could notice the strong belief of the Muslim woman and the extremely important role that the Islam has in her way of thinking, mentality and feelings". ${ }^{12}$

Despite all the above-stated on the situation of monogamous marriage in European countries, in "the Islamic state" a man can have up to 4 wives - "get married to your pleasure with two, three or four women..." (4: 3 Qur'an).

Polygamous marriage continues to be a controversial subject, with particular problems occurring internationally in applying the rules of private international law, when such marriages involve "non-Muslim" persons. In the opinion of Muslims, "misconceptions about this traditional Islamic institution are widespread and strongly condemned by non-Muslims because the first image outlined in the minds of these is that Islam is a religion that encourages sexual indulgence of men in society and the subjugation of women through this

\footnotetext{
11 Please refer to Oana Ghiţă, Roxana Gabriela Albăstroiu, Dreptul familiei. Regimuri matrimoniale, Ed. Humanitas, Bucureşti, 2013, p. 14 and the following.

12 Cristina Otovescu Frasie, "The Women's Rights in the Islamic World", AGORA International Journal of Juridical Sciences, Agora University Press, Oradea, no.2/2011, p. 419.
} 


\section{EUROPEAN}

hereditary system." ${ }^{13}$ In supporting polygamous marriage, Arabic doctrinaires ${ }^{14}$ inform those who do not show their adhesion to such principles that the conclusion of a polygamous marriage envisages compliance with some very strict rules, which we will briefly enumerate:

- The institution of polygamy is confirmed in principle by the Qur'an; limitations;

- The status of polygamy in Islam is one of permission which presents clear

- The practice polygamy arose as a way to protect widows and orphans - "social necessity and not someone's fantasy or indulgence" ${ }^{\prime 15}$;

- A man should be able to financially keep their wives;

- A man must treat all wives in a completely equal manner.

To these rules, others can be added which are more or less accepted by some Arabic authors ${ }^{16}$. A man can marry a second woman if his first wife:

- Cannot have children;

- Proves to be disobedient;

- Has a nasty character from the point of view of her husband;

- Does not take care of her husband to his liking etc.

\section{Concluding a Marriage}

As we saw in the enumeration of facts set out in the Shari'ah, every Muslim man must enter into marriage. "Marriage in Islam is noble and necessary in general as it brings tranquility, procreation and the continuation of life with purity and responsibility. Marriage is an act of worship; it provides a legal relationship between a man and a woman, and most importantly, provides a means to fulfill the divine purpose of human procreation and human relations." ${ }^{17}$

According to Shari'ah, a man can marry a female child who has reached the age of 1 year and may have sex with her once she has reached the age of 9 years. To conclude this marriage the man must pay the girl's family a dowry. ${ }^{18}$

Some doctrinaires ${ }^{19}$ say that the dowry is no longer usually paid in most Muslim countries to the girl's family, but to the woman herself, because Islam gave women the right to property.

To legally conclude a valid marriage, several conditions must be met:

- There are no impediments to the marriage; these include well known Shari'ah impediments regarding the impossibility of concluding the marriage of some people which have "blood or milk ties";

- To have the consent of themselves and their families;

- Legal formalities to be fulfilled;

- To pay the dowry - as we see it is not necessary to specify this in the contract what or how much the dowry represents, but only that it be paid after the conclusion of the contract or, in certain circumstances, after consummating the marriage.

There are a few well known impediments to marriage:

- Kinship by blood or marriage, co-lactation, oath of anathema - standing impediments;

- Mixed religion, the triple repudiation, kinship between the wives of the same husband, the idda period - temporary impediments.

\footnotetext{
${ }^{13}$ Muslim Women's Association, op. cit., p. 73

${ }^{14}$ Jamal A. Badawi, Poligamia în Legea islamică, Ed. American Trust, Indiana, 1976, p. 1.

${ }^{15}$ Eliz Sanasarian, Activismul politic şi identitatea islamică în Iran, în Lynne B. Iglitzin şi Ruth Ross (coord.), Femeile în lume 1975-1985, ed. a II-a, Ed. Santa Barbara, California, 1986, p. 215.

${ }^{16}$ Halef Afshar, Femeile, Statutul şi Ideologia, Ed. Macmillan, Londra, 1987, pp. 78-81.

${ }^{17}$ Muslim Women's Association, op. cit., p. 124.

${ }^{18} \mathrm{http}: / / \mathrm{www}$. pointsdereperes.com/articles/condition-femme-musulmane

${ }^{19}$ S. A. Aldeeb Abu-Sahlieh, op. cit., p.151.
} 


\section{O. Ghiţă}

The impediment of marriage between persons related by blood or by marriage leads to the category "of prohibited persons" (maharim) which comprises ascendants and descendants and their spouses, the sister and descendants of siblings, aunts, sisters and aunts of ancestors, the mother and offspring of the wife. It is allowed to marry between cousins (collaterals four times removed).

The oath of anathema is the formula which invokes the wrath of God against adulteress women, which even at present leads to adverse social consequences for the woman who has suffered such an oath, the penalty is most often death, especially when she becomes pregnant because of the adultery.

Regarding mixed marriages between people of different religions, certain clarifications must be made: is not allowed for a Muslim woman to marry a non-Muslim man. However, it is possible for a Muslim man to marry a woman belonging to a revealed religion (Christianity and Judaism).

The idda period - withdrawal continence - is a period of four months and ten days between two consecutive marriages in which the woman is forbidden to marry or have sex in order not to give rise to doubts about a possible pregnancy.

We notice that the conditions which need to be observed upon marriage do not have too much in common with the conditions to be fulfilled by a European citizen, in general, to conclude a valid marriage. In the Romanian legal system, the conditions are set out in articles 271-277 of the Civil Code, in which we find all aspects concerning both positive background conditions (consent, age, marital status, sex difference) and impediments (bigamy, natural or blood kinship, guardianship, insanity and mental illness). To these are added the substantive conditions and formalities to be observed at the marriage, provided for in articles 278-292 of the Civil Code.

During marriage, Muslim women have the right to be financially kept by her husband. Given that social repartition of activities has been made, as stated in Arabic literature, according to physical abilities and spiritual needs of women and men, quite often a woman cannot to have a job, because she is the one that takes care of the household and the children, and her husband is the one who financially support the whole family.

The husband's financial obligations include:

\subsection{The Wife's Dowry}

As we have mentioned earlier, in order to conclude the marriage, the husband must provide a dowry to the wife or her family. This dowry must be given when:

- A valid marriage contract is concluded, in which case the whole or part of the dowry is returned if the marriage is not confirmed or consummated or if the woman dies before its consummation.

- The actual consummation of a marriage, which was not validly concluded, in which case the man must pay the full dowry, if not forgiven by the woman.

We must keep in mind that the dowry does not represent a prerequisite to marriage, but a result of its conclusion. Thus, the fact that it was not stipulated within a marriage contract, does not prevent its valid conclusion, but once completed, the payment of the dowry becomes mandatory for the man.

No text of the Qur'an or Shari'ah provides a minimum or maximum value of the dowry, however it is believed that "the woman is entitled to a dowry equal to that of her peers upon the conclusion of a marriage" ${ }^{20}$. Besides, the dowry can be represented by any sum of money or any property that can be capitalized, a title of ownership or assignment of a debt.

In the Romanian legal system, the dowry appears somewhat different, being regulated by the Civil Code of 1864 as a matrimonial conventional regime with separation of assets that represented the legal regime. Currently this matrimonial regime no longer exists, the 2011

\footnotetext{
${ }^{20}$ Muslim Women's Association, op. cit., p. 33.
} 


\section{EUROPEAN}

Civil Code regulations are adapted to the social realities of the moment. Thus, we find stipulated that legal matrimonial regime - the regime of community of property (articles 339359 of the Civil Code.) and conventional regimes: the regime of separation of property (articles 360-365 of the Civil Code.) and conventional community regime (articles 366-368 of the Civil Code.)

\subsection{Marriage Expenses}

Marriage expenses include several categories of costs. First are those costs incurred by marriage: the marriage contract, the marriage celebration. The wife or her family is not obliged to contribute to these expenses. Also, only where desired, she may bear some of the dowry costs, but most often this does not happen.

It is also the husband who takes care of the provision of housing for the family, as well as its setting. Whatever the material possibilities of the husband may be, he is obliged to ensure his wife with a space in which she is not obliged to wear a hijab. "Every woman needs an area in which she is not forced to wear hijab, whether it involves an apartment for her, her house, her bedroom in an extended family home or even an area with a curtain of a barracks or hut, if in a precarious financial situation"21

When it is the husband who contributes exclusively to the purchase of the house and its arrangement, it becomes his personal property, and his wife is granted a right of use of the residence and its accessories under the permission given by her husband. In some countries, the married woman's family may request that all the furnishings and decoration for the home be included in the dowry, recording them all in a list of household items and wedding jewelry.

Likewise, in other states the family of the future wife may help buy and prepare the necessary items for the family home. Depending on the will of the father of the bride, these goods will be the married couple's property, or may be just on loan until they are requested by the bride's family.

A third category of expenditure within a marriage agreement is the financial support that the wife owes her husband regardless of her physical condition. The husband must provide his wife, food, clothing, medical treatment and anything else she may need that is not disproportionate to the financial situation of the husband.

In the Romanian legal system the statement of expenditure is provided by the Civil marriage in a special way, by mandatory rules, under the primary imperative scheme (article 325-328 of the Civil Code). In these pieces of legislation, it is required for spouses to contribute to the marriage expenses within each other's means, but it also provides that the household work of either spouse is a contribution to the marriage expenses.

In the same manner, is the special legal status of the family home regulated (articles 321-324 of the Civil Code). This is the house where spouses and their children actually carry on family life and is legally protected by any act done by one of the spouses - even a sole owner - without the permission of the other and that could lead to the loss of the family house or furnishings and decorations.

\section{Dissolution of marriage}

Both the Qur'an and the Shari'ah do not encourage divorce, but ban it. Even on a social level, Muslims that go through a divorce, where it is allowed, are subjected to public scorn and become marginalized by the community to which they belong. In theory, in order to not be so "distant" from Western civilization, the possibility of divorce is allowed at the request of either or both spouses, when there are serious reasons affecting the marriage, and its continuation it would have highly serious effects on the family members.

Divorce may have two very different forms:

- Divorce at the request of the husband (talak) or repudiation occurs only if the marriage was consumed and represents a suite of procedures that are initiated by the husband

\footnotetext{
${ }^{21}$ Idem, p. 15.
} 


\section{O. Ghiţă}

who pronounces a sacramental formula followed by a period of separation in fact. This must be repeated three times. If after the third separation an agreement is not reach between spouses or the husband does not forgive his wife, the separation will be final.

The former husband will no longer be able to remarry the repudiated woman after the marriage ends and she gets remarried. Or, in the past not only could the repudiated woman not marry again, but more than that, once returned to her family, she was killed in order to remove the traces of any dishonor.

Repudiation by the husband can be done without this period of repeated separation by uttering three times the sacramental formula.

- Proper divorce (or tarliqa tatliq) is the divorce pronounced by the kadi at the request of the man or woman for very serious reasons. There are still many Muslim states that do not allow this form of divorce, because most Muslim countries do not give the woman the opportunity to get out of the marriage by her will.

Moreover, there are situations where divorce is granted to women in extremely difficult conditions, and the consequences are extremely serious. For example, a woman who was subjected to rape by her husband and accuses him of it must prove the rape through four male witnesses. Once proven, the woman will be sent back to his family who will have to return the dowry to the former spouse. To erase the dishonor done to by the wife who has failed to maintain the marriage and that certainly will not be able to contract a new marriage, the families of these women choose to kill them..$^{22}$

In the Romanian legal system, even before the entry into force of the Civil Code there was the possibility of spouses to divorce by mere agreement. This dissolution of marriage may be carried out, under the law by the competent court or notary or the justice of the peace. Also, there is also the option of divorce due to the fault of one or both spouses, divorce at the request of either spouse after a separation which lasted at least two years or dissolution of marriage at the request of one spouse whose state of health makes it impossible to continue the marriage (according to article 373 of the Civil Code.).

\section{Conclusion}

At a mere enunciation of rules laid down in the Qur'an and Shari'ah or the way they are interpreted we understand immediately that we are talking about quite a different value system than any known to the European citizens, not to mention that to say that a clear and timely comparison of the European legal system with the Muslim legal system is impossible.

This different "vision" of legal values regarding women's rights that the "Islamic state" has towards the West has its source in a well-established tradition firmly implanted in the social consciousness and nurtured by experience and education during many generations. Muslim women, while enclosed in the cultural cage that religion provides under the watchful eye of the father or the husband - because most times she is illiterate - is subject to the husband and not the protection that he should offer her as the Holy Book prescribes in its ideas.

\section{References:}

Muslim Women's Association, Femeia în Islam, Ed. Femeia musulmană, Bucarest, 2013. Oana Ghiţă, Roxana Gabriela Albăstroiu, Dreptul familiei. Regimuri matrimoniale, Humanitas Publishing, Bucarest, 2013.

Cristina Otovescu Frasie, The Women's Rights in the Islamic World, AGORA International Journal of Juridical Sciences, Agora University Press, Oradea, Romania, no. 2/2011. Y. Al-Qaradawy, Statutul femeilor în Islam, Taiba Publishing, Bucarest, 2008.

\footnotetext{
${ }^{22}$ http://www.pointsdereperes.com/articles/condition-femme-musulmane
} 


\section{EUROPEAN}

S. A. Aldeeb Abu-Sahlieh, Projets de constitutions et droits de l'homme islamique, Studia Arabica VIII, Paris Publishing, 2008.

M. Agi, Islam et droits de l'Homme, Des Idees et Des Hommes Publishing, Paris, 2007.

Katerina Dalacoura, Islam, Liberalism et Human Rights, ed. a 3-a, I.B.Tauris Publishing, London, 2007.

Ş. Reşceanu, Islamul între istorie şi modernitate, Universitaria Craiova Publishing, 2007.

S. H. Nasr, Islam. Perspectives et realites, Buchet/Chastel Publishing, 1991.

Halef Afshar, Femeile, Statutul şi Ideologia, Ed. Macmillan, Londra, 1987.

Eliz Sanasarian, Activismul politic şi identitatea islamică în Iran, în Lynne B. Iglitzin și Ruth Ross (coord.), Femeile în lume 1975-1985, IInd edition, Santa Barbara Publishing, California, 1986.

Kuwait colloquium was organized by the International Commission of Jurists, the University of Kuwait and the Arab Lawyers' Union, Kuwait, 9 to 14 December 1980.

J. A. Badawi, Poligamia în Legea islamică, American Trust Publishing, Indiana, 1976.

http://www.pointsdereperes.com/articles/condition-femme-musulmane 